\title{
Teaching Science Education with Poetry
}

\author{
Larissa Macalão Barbosa1, Braulio Fonseca ${ }^{2}$, Rossano André Dal-Farra ${ }^{3}$, \\ Leticia Azambuja Lopes ${ }^{3,4}$ \\ ${ }^{1}$ Prefeitura Municipal de Canoas, Secretaria Municipal de Educação, Canoas, Brazil \\ ${ }^{2}$ Governo do Estado do Rio Grande do Sul, Secretaria Estadual de Educação, Canoas, Brazil \\ ${ }^{3}$ Universidade Luterana do Brasil, Programa de Pós-graduação em Ensino de Ciências e Matemática, Canoas, \\ Brazil \\ ${ }^{4}$ Bolsista PNPD/CAPES, Canoas, Brazil \\ Email: seduc.prof.larissa@gmail.com, bpf rs@hotmail.com, rossanodf@uol.com.br, leazambuja@gmail.com
}

Received 23 September 2014; revised 10 October 2014; accepted 18 October 2014

Copyright (C) 2014 by authors and Scientific Research Publishing Inc.

This work is licensed under the Creative Commons Attribution International License (CC BY).

http://creativecommons.org/licenses/by/4.0/

(c) (i) Open Access

\begin{abstract}
The main objective of this paper is to describe the process of integration of the disciplines of arts and sciences through poems written by pupils of a public school in southern Brazil. First, the teachers wrote and read a poem in classroom for pupils of the fifth to eighth grade. After, pupils wrote a poem about science subjects, aiming to improve the learning of concepts of physics, chemistry, and biology inspired by their own poetic vision on science and nature. The results address the work to improve the utilization of poetry in learning science, contributing to the development of an interdisciplinary method integrating different sources of knowledge and, mainly, students, teachers, and learning.
\end{abstract}

\section{Keywords}

Elementary School, Science Education, Poetry, Interdisciplinarity

\section{Introduction}

The book “Order Out of Chaos” written by Ilya Prigogine and Isabelle Stengers inspired an interdisciplinary interaction process utilizing science education and arts education with students of an elementary school. According to Prigogine and Stengers (1991), the scientific knowledge, extracted from dreams of an inspired revelation, [...] can be discovered nowadays as a poetic listening about nature and, simultaneously the natural process itself, and start a process of production and invention, forming an open world and a productive and inventive process.

The beginning of process occurred followed by the expression "listening to the poetic nature" instigating researchers to redeem this view of nature, integrating knowledge derived from different times and spaces. 
According to Moreira (2002), there are profound relations among science, culture and arts in the process of human creation. However, this is often not seen in our classrooms, which are characterized by fragmented activities.

In recent years, teachers have frequently observed books heavily reported in the media as if they were waves of enchantment by fictional characters of J. K. Rowling, Rick Riordan and other authors. Likewise, the decisive inclusion of social media in the lives of students put teachers in a great dilemma: Fight or join in with contemporary cultural movement?

In this case, imbued with the need to integrate the knowledge of science with other aspects of daily life with the care setting boundaries between what is relevant and what needs to be viewed with caution by teachers, teachers sought to build, with students, an educational process at the same time is exciting and that may be facilitated by the enchantment of scientific knowledge.

Given these assumptions, this study aims to establish a starting point intending new educational practices whose underlying principles are the integration of knowledge across disciplines and activities performed by students outside school, as well as the promotion of learning in science in other fields of knowledge.

Fazenda (2008) points out that interdisciplinarity means attitude about knowledge involving the culture of the place where teachers are formed.

The use of composition as a teaching method in areas that go beyond literature or language is widely adopted in the teaching of sciences and mathematics (Faria, 1998; Santos, 2001; Zanetic, 2006; Galvão, 2006; Silva \& Reigota, 2010).

The objective of this study is to construct educational practices integration of the disciplines of arts and sciences through poems written by pupils of a public school in southern Brazil.

\section{Method}

Students attending classes between the $5^{\text {th }}$ and the $8^{\text {th }}$ grades of an elementary public school in southern Brazil were required to write poems. In total, seven groups of students participated, totalizing more than one hundred students.

With more than 300 thousand inhabitants and approximately 2470 inhabitants per $\mathrm{km}^{2}$, the city has an HDI of 0.75 and per capita GDP is close to $\$ 6500.00$, although there is significant heterogeneity in the socioeconomic profile of the population. There are more than 49,000 primary school enrollment and approximately 11,000 in high school.

The theoretical framework developed by Ilya Prigogine was supplemented with a literature review of sciences textbooks and the evaluation of the knowledge provided therein, which could be used from the poetic perspective.

However, when the sciences teacher walked into the teachers' room, she overheard another teacher saying, "My students are glued to Facebook", and added, "If they are always logged on, I should be too". Later on, the teacher posted a poem on the social network. To her surprise, on the following class the students asked about what she had written and if it she had written the poem herself.

Initially, a pedagogic proposal was presented to the school board. The aim was to challenge students to write poetry about sciences and nature. The pedagogic directions for the process and the pedagogic boundaries of the formal evaluation of the poems written were outlined, and the first moves were started to motivate students to write their poems.

In each group, two poems written by the teacher were red at the beginning of classes, on two different days. Additionally, two other poems, also written by the teacher were published on her Facebook wall.

Facebook was chosen as a medium to divulge poems for different reasons. First, it was discovered that "students are always logged on". Therefore, it became clear that they would easily publish one poem on a popular social network that they use often. Moreover, there is the possibility to divulge poems quite easily, which affords students to read one another's poems and reinforces the emotional links between them, who usually attend the same class or at least the same school, even though sometimes they have never actually met. Another aspect is that Facebook is an "effective and affective platform" for teachers and students, since the sciences teacher and even members of the school board would post positive comments about poems. In sum, all participants of the school community would have access to these poetic productions, even family members and school board officials. 
A deadline was defined for the posting of poems on the teacher's Facebook wall. Poems were posted according to the rules defined previously.

\section{Results and Discussion}

The results presented are preliminary, since the process of writing poetry has not ended yet. In total, so far 57 poems were published. The main topics are the solar system, the oxygen flow in the respiratory system, and, mainly, the periodic table. Some poems written by students are reproduced at the end of article.

Students participated actively in this project. The literary production of poems shows that the aim of stimulating imagination, integrating knowledge and contributing with inclusion of students was met. This confirms the ideas of Bachelard (1994), according to which the learning process has to be dynamic and connected to the imagination and creative capacity of students. Subsequently, students read their poems to their classmates, adding their own personal impressions about the process and developing communication skills, which is an important aspect in personal and professional life.

The continuity of activities was mediated by the narrowing of the conceptual dimension involved in sciences and the text production process, helping students to integrate knowledge that they already master and develop new knowledge that is useful in the comprehension of the fundamental concepts of scientific education.

This study shed new light on the potentials to be developed by students that sometimes do not emerge in activities carried out in school.

The educational process needs to integrate knowledge of different sources, constructing new kind of practices because the life of students are made not only in classrooms but also the readings and look at the world around them. Science, Literature, popular knowledge? Whatever? The student needs to develop all the potential they possess and that can contribute to their lives.

\section{References}

Bachelard, G. (1994). O Direito de sonhar (4th ed.). Rio de Janeiro: B.Brasil.

Faria. C. O. (1998). Redação matemática: A comunicação como mediadora na formação de conceitos matemáticos. Inter-Ação, 22, 12-32.

Fazenda, I. (2008). O que é interdisciplinaridade? São Paulo: Editora Cortez.

Galvão, C. (2006). Ciência na literatura e literatura na ciência. Interaç̧ões, 3, 32-51. http://repositorio.ipsantarem.pt/bitstream/10400.15/225/1/C3.pdf

Moreira, I. C. (2002). Poesia na sala de aula de ciências. A literatura poética e possíveis usos didáticos. Física na Escola, 3 , 17-23.

Prigogine, I. (1991). A Nova Aliança. Brasília: Editora Universidade de Brasília.

Santos, M. B. S. (2001) Escrever, para quê?! A redação mediando a formação de conceitos. Inter-Ação, 26, 1-16. http://www.revistas.ufg.br/index.php/interacao/article/view/1605/1561

Silva, A. A., \& Reigota, M. (2010). Ciência e poesia em diálogo: Uma contribuição à educação ambiental. Quaestio, 12, 139-153.

http://periodicos.uniso.br/ojs/index.php?journal=quaestio\&page=article\&op=view\&path\%5B\%5D=196\&path\%5B\%5D=1 $\underline{96}$

Zanetic, J. (2006). Física e literatura: Construindo uma ponte entre as duas culturas. História, Ciências, Saúde, 13, 55-70. http://dx.doi.org/10.1590/S0104-59702006000500004 


\section{Appendix}

\section{Poems about the Solar System}

The solar system

Is beautiful to see

But I cannot touch it

There is Pluto

So small it is

That it is no planet anymore.

Now it is a dwarf!

Mercury was named after a chemical

And Venus looks like an egg

With $1 \%$ of water to give

Mars even has a volcano

And four seasons.

Jupiter is the largest

With 100 Earths within

Saturn has its rings

Uranus is the newest and hardest

Rock hard and full of ice

Neptune is the sky-blue planet!

Earth is full of people

Who do not sense the value of this gift!

In our solar system

There is Mercury and Saturn

And frozen planets

The gaseous, lighter ones

The new planet is, yes, Pluto

A dwarf globe

People say, yes it is!

Scientists say, no it is not!

Some are also made of water

Frozen is the sea

Oceans on Earth are several

No air there is in Mercury

Our planet spins and spins

Spins nonstop

If it did stop suddenly

We earthlings would land on the Moon

Always pure, always beautiful

Is our universe

I shall end like a sonnet

Sticking to my verse

\section{Poems about the Respiratory System}

This is about the respiratory system

Which makes us breathe

Let the adventure begin

Respiratory system

From end to end of this mayhem

That starts on nose and mouth

There goes oxygen down this jinx 
Through larynx and pharynx

To trachea it is

Knocking at the lungs and diaphragm

So it travels and is given!

Carbon dioxide is released

And thus it is forsaken!

It starts at the nose

Where oxygen comes in

All perfect, who knows...

It's a genius thing

It goes on and on

Larynx, trachea, lungs

Filled with air

These are the organs, and their roles

That makes us breathe

Inside lungs there are alveoli

Where oxygen and carbon dioxide

Swap places

And even though there is a lot to say

I say goodbye to this jesting rhyme

\section{Poems about Chemistry}

In Helium I laughed and had fun In Sulphur got cross, life was hard And on Sodium I wept

But things fly by, and with Oxygen I live and will be kept From the bitter that sodium begun In chemistry opposites come near The different repel Experiments show It is easy to see

In humans is the way round

Similar joins similar

And if there is chemistry in between

There will be joy to live 
Scientific Research Publishing (SCIRP) is one of the largest Open Access journal publishers. It is currently publishing more than 200 open access, online, peer-reviewed journals covering a wide range of academic disciplines. SCIRP serves the worldwide academic communities and contributes to the progress and application of science with its publication.

Other selected journals from SCIRP are listed as below. Submit your manuscript to us via either submit@scirp.org or Online Submission Portal.
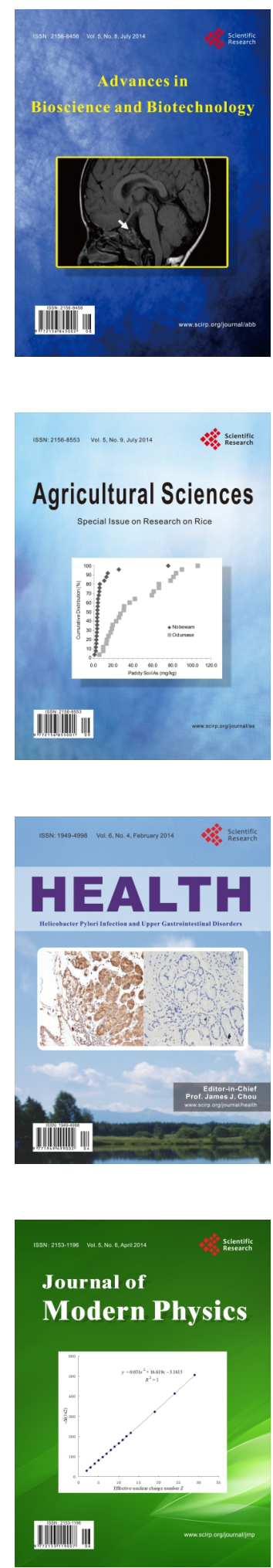
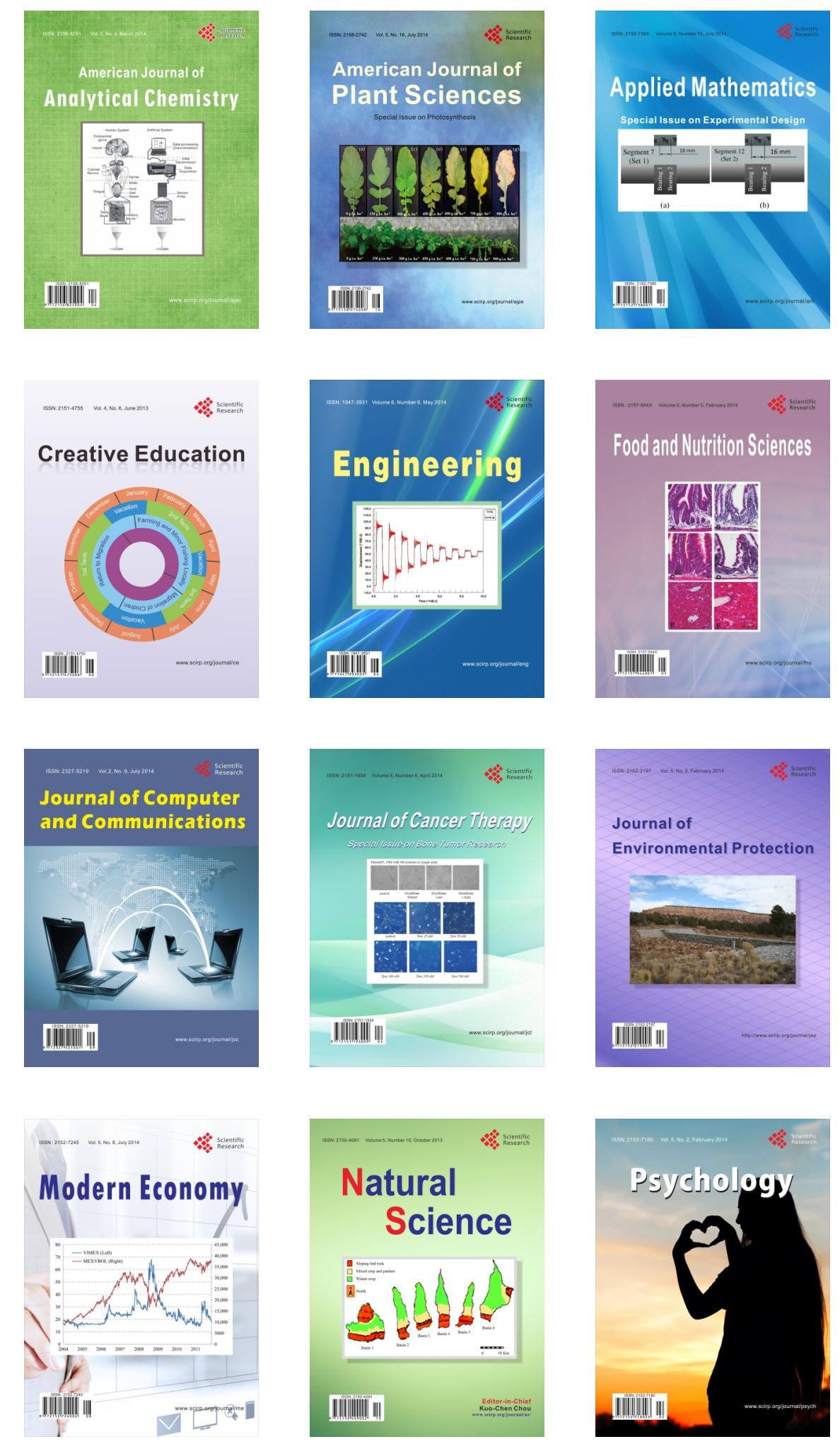